\title{
ANALISIS PERBANDINGAN REKSA DANA SAHAM SYARIAH DENGAN REKSA DANA SAHAM KONVENSIONAL PERIODE 2009-2012
}

\author{
Mulya Riyady Esha; Mohamad Heykal; Titik Indrawati \\ Accounting and Finance Department, Faculty of Economic and Communication, BINUS University \\ Jln. K. H. Syahdan No. 9, Palmerah, Jakarta Barat 11480 \\ m_heykal@binus.ac.id
}

\begin{abstract}
The purpose of this study is to measure performance of sharia equity fund compared conventional equity fund and to find out whether the performance of sharia equity fund and conventional equity fund could outperform the market. The research method is annual return, risk adjusted return, and snail trail. The research object is equity fund that has been stated effective by Bapepam - LK before the research period. Result from this study is sharia equity fund has a better performance, a few of equity fund can outperform from the market, and the result of statistic test declares that there is not any different average performance of sharia equity fund and conventional equity fund with Significance level (0.05). Conclusion of the study is sharia equity fund have better performance and it could be compared with conventional equity fund.
\end{abstract}

Keywords: sharia equity fund, conventional equity fund, annual return, risk adjusted return, snail trail

\begin{abstract}
ABSTRAK
Tujuan penelitian ialah untuk mengukur kinerja reksa dana saham syariah di bandingkan dengan kinerja reksa dana saham konvensional serta untuk mengetahui apakah kinerja dari reksa dana saham syariah maupun konvensional dapat mengalahkan pasar. Metode yang digunakan adalah annual return, risk adjusted return, serta snail trail. Objek yang diteliti adalah reksa dana saham yang dinyatakan efektif oleh Bapepam LK sebelum periode penelitian. Dari penelitian yang dilakukan hasil yang dicapai adalah kinerja reksa dana saham syariah lebih baik dibandingkan kinerja reksa dana saham konvensional, terdapat beberapa reksa dana saham yang dapat mengalahkan pasar, serta dari hasil uji statistik menyatakan bahwa tidak ada perbedaan rata-rata kinerja reksa dana saham syariah dengan reksa dana konvensional pada Significance level (0.05). Sehingga dapat disimpulkan reksa dana saham syariah memiliki kinerja yang tidak kalah dengan reksa dana saham konvensional dan layak untuk diperbandingkan.
\end{abstract}

Kata kunci: reksa dana saham syariah, reksa dana saham konvensional, annual return, risk adjusted return, snail trail 


\section{PENDAHULUAN}

Pada dasarnya reksa dana syariah dan reksa dana konvensional tidak jauh berbeda, yaitu sebagai wadah untuk mengumpulkan dana dari masyarakat yang selanjutnya diinvestasikan ke pasar modal dan pasar uang oleh Manajer Investasi. Reksa dana syariah memiliki kriteria yang berbeda dengan reksa dana konvensional pada umumnya. Perbedaan pertama terletak pada pemilihan instrumen investasi. Reksa dana syariah hanya menempatkan dananya pada instrumen yang bebas dari praktek riba dan praktek-praktek yang tidak halal menurut syariah dan mekanisme investasi tidak boleh bertentangan dengan prinsip-prinsip syariah. Mekanisme operasional reksa dana syariah antara pemodal dan Manajer investasi adalah dengan Wakalah, sedangkan antara Manajer Investasi dengan pengguna investasi dengan sistem Mudharabah. Perbedaan lainnya adalah keseluruhan proses manajemen portofolio, screening (penyaringan), dan cleansing (pembersihan).

Ridho (2008), melakukan penelitian tentang Perbandingan kinerja reksa dana konvensional dan syariah dengan indeks sharpe, treynor dan jensen (periode tahun 2003-2007) menjelaskan bahwa perbandingan rata-rata kinerja Reksa Dana Campuran baik itu Konvensional maupun Syariah dengan periode 01 Januari 2003 - 31 Desember 2007 hasilnya menunjukkan bahwa rata-rata kinerja ketiga indeks, baik Sharpe, Treynor maupun Jensen, tidak ada perbedaan secara signifikan pada alpha 5\%. Rachmawati (2008), melakukan penelitian tentang Komparasi kinerja reksadana Syariah dan reksadana konvensional kategori saham, campuran, dan pendapatan tetap di Indonesia periode Maret 2005-Maret 2008 menjelaskan bahwa dari sebagian besar perusahaan investasi yang menjadi objek penelitian, kinerja produk reksa dana berbasis syariah yang dikelolanya lebih unggul dibandingkan dengan kinerja reksa dana berbasis konvensional.

Tujuan dari penelitian ini adalah Untuk membandingkan kinerja reksa dana syariah dan reksa dana konvensional. Mengevaluasi kinerja tahunan reksa dana syariah maupun konvensional dengan jenis reksa dana saham. Mengetahui dan memberikan Informasi mengenai kinerja reksa dana saham syariah dan reksa dana saham konvensional sebagai pembanding.

\section{METODE}

Penulis akan melakukan penelitian mengenai perbandingan kinerja reksa dana saham syariah dengan reksa dana saham konvensional pada periode Januari 2009 - Desember 2012. Jenis penelitian yang dilakukan adalah penelitian kuantitatif. Dalam penelitian ini penulis menggunakan banyak sampel dalam empat periode waktu. Metode pengumpulan data yang dilakukan adalah tidak langsung, yaitu berupa data yang telah dikumpulkan oleh pihak lain dan dipublikasikan ke masyarakat. Hal ini terjadi karena data-data yang diambil dalam penelitian ini banyak mempergunakan data data sekunder. Metode yang digunakan penulis dalam penelitian ini adalah annual return, risk adjusted return dan metode Snail Trails

\section{HASIL DAN PEMBAHASAN}

Dalam bab ini analisis akan dibagi menjadi dua bagian, yaitu analisis dari uji statistik yang telah dilakukan dan selanjutnya adalah analisis berdasarkan metode yang telah ditentukan sebelumnya 


\section{Uji Statistik}

Uji Normalitas; Pengujian normalitas data-set reksa dana saham akan menggunakan uji normalitas - Kolmogorov Smirnov. Berdasarkan hasil uji normalitas dengan Kolmogorov Smirnov pada semua data-set reksa dana saham baik itu syariah maupun konvensional, nilai signifikansi pada semua data-set reksa dana saham mendekati 0 yang menyatakan semua data-set tidak terdistribusi dengan normal. Namun pada kasus data-set yang berjumlah besar seperti masing data-set berjumlah 1219 data, maka hasil dari uji normalitas - Kolmogorov Smirnov dapat kita abaikan dan menganggap bahwa data-set reksa dana saham normal (Gujarati,2009)

Uji T ( T-Test ); Tujuan dari uji statistik ini adalah untuk mengetahui apakah kinerja dari reksa dana saham syariah bisa diperbandingkan dengan kinerja reksa dana konvensional. Yaitu dengan melihat apakah ada perbedaan rata-rata antara kinerja reksa dana syariah dan reksa dana konvensional dengan melakukan uji $\mathrm{T}$ (T-Test) atau uji beda rata-rata dua kelompok dengan sample independent di dalam penelitian ini. Dalam uji statistik ini perhitungan benchmark dari masing-masing reksa dan tidak diikut sertakan. Significance level yang digunakan adalah sebesar 0.05 atau dengan confidence level sebesar 95\% dengan menggunakan hipotesis sebagai berikut: (a) $\mathrm{H}_{0}$ : "Tidak ada perbedaan ratarata kinerja reksa dana saham syariah dengan reksa dana saham konvensional" (b) $\mathrm{H}_{1}$ : "Terdapat perbedaan rata-rata kinerja reksa dana saham syariah dengan reksa dana saham konvensional"

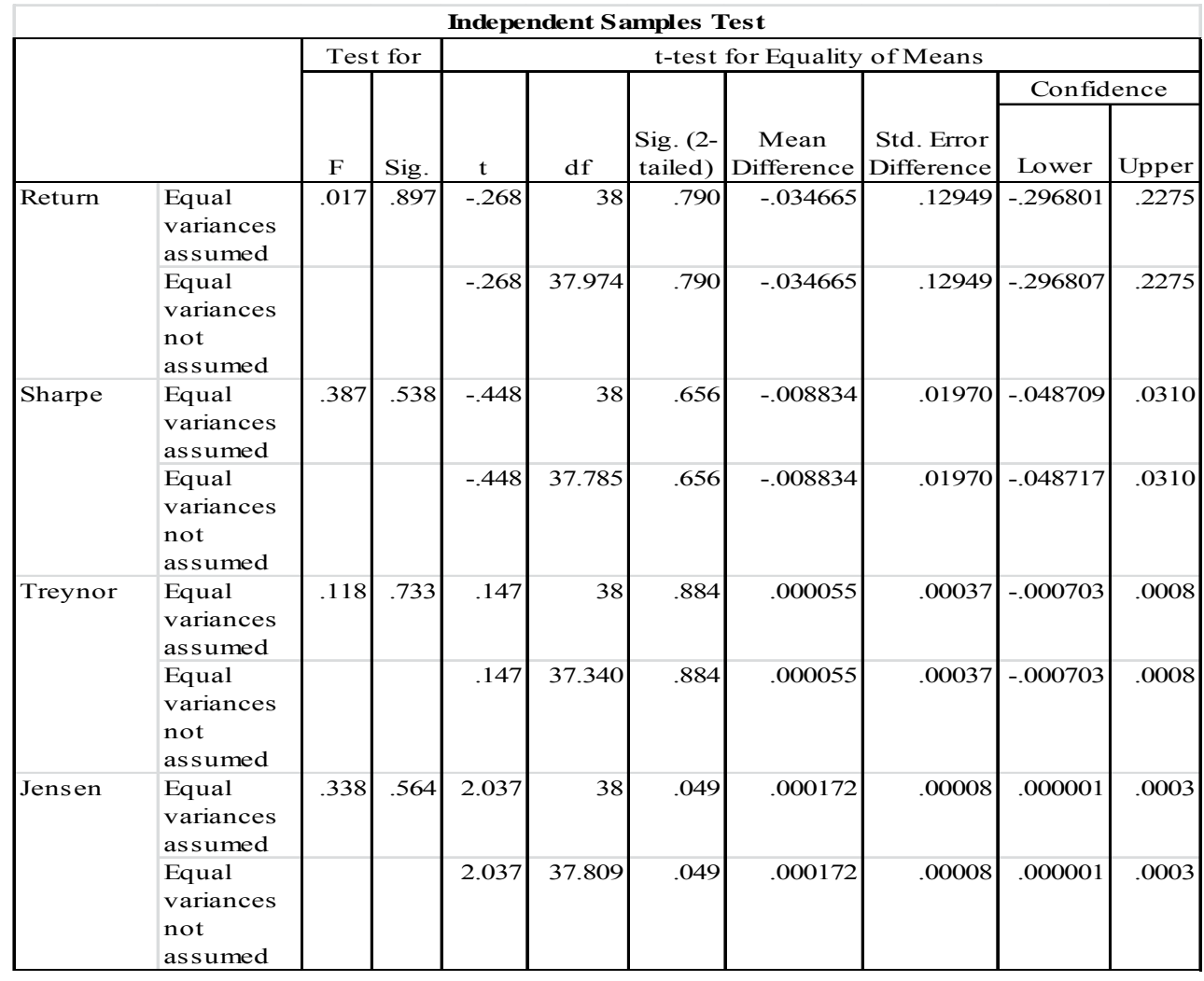

Gambar 1 Independent Sample Test

Sumber: Data Olahan

Yang harus diperhatikan dalam pengujian statistik dengan menggunakan Uji T (T-Test) adalah nilai Sig. yang dihasilkan dari tabel uji T diatas. Dari tabel uji T diatas nilai Sig. dari Return sebesar 0.897 , Sharpe 0.538, Treynor 0.733, Jensen 0.564. Karena semua Sig. yang di hasil kan dari uji $\mathrm{T}>$ dari Significance level (0.05) maka $\mathrm{H}_{0}$ diterima, sehingga secara statistik tidak ada perbedaan rata-rata 
kinerja reksa dana saham syariah dengan reksa dana saham konvensional. Berdasarkan uji statistik ini pula dapat disimpulkan bahwa kinerja kedua reksa dana saham tersebut memang bisa diperbandingkan.

\section{Kinerja Reksa Dana Saham}

Peneliti akan memperlihatkan data olahan yang dapat digunakan untuk menganalisa kinerja reksa dana saham syariah maupun konvensional. Data ini juga dapat mengambil kesimpulan tentang kinerja reksa dana syariah maupun konvensional. Pembahasan tentang kinerja reksa dana saham peneliti bagi dalam tiga bagian: (a) Annual Return. (b) Risk Adjusted Return - Sharpe Ratio, Treynor Ratio, Jensen Ratio. (3) Return dan risiko - Snail Trail.

Sebelum masuk kedalam analisis reksa dana saham, ada baiknya untuk melihat pertumbuhan Net Assets Value (NAV) serta unit penyertaan (UP) dari semua reksa dana saham yang akan di teliti, baik itu syariah maupun konvensional. Pertumbuhan NAV dan UP semua reksa dana saham dapat dilihat pada tabel 1 dan 2 berikut ini

Tabel 1 Pertumbuhan Net Asset Value (NAV) Periode 2009 - 2012

\begin{tabular}{rlrrrr}
\hline$\#$ & RDS & $\mathbf{2 0 0 9 / 2 0 1 0}$ & $\mathbf{2 0 1 0 / 2 0 1 1}$ & $\mathbf{2 0 1 1} / \mathbf{2 0 1 2}$ & $\mathbf{2 0 0 9 - 2 0 1 2}$ \\
\hline 1 & Batavia_S & $-21.44 \%$ & $-19.54 \%$ & $404.90 \%$ & $219.17 \%$ \\
2 & Batavia & $12.93 \%$ & $16.65 \%$ & $100.32 \%$ & $163.89 \%$ \\
3 & Trim_S & $4.02 \%$ & $-20.89 \%$ & $88.23 \%$ & $54.89 \%$ \\
4 & Manulife & $-5.34 \%$ & $-18.23 \%$ & $-8.07 \%$ & $-28.85 \%$ \\
5 & Mandiri_S & $31.25 \%$ & $-69.77 \%$ & $19.82 \%$ & $-52.45 \%$ \\
6 & NISP & $2.27 \%$ & $-8.39 \%$ & $-50.62 \%$ & $-53.74 \%$ \\
7 & BNP & $-45.06 \%$ & $-36.82 \%$ & $9.40 \%$ & $-62.03 \%$ \\
8 & PNM_S & $-52.69 \%$ & $-22.18 \%$ & $-2.90 \%$ & $-64.25 \%$ \\
9 & Danareksa & $-16.29 \%$ & $-49.56 \%$ & $-41.40 \%$ & $-75.26 \%$ \\
10 & CIMB_S & $-51.46 \%$ & $-73.31 \%$ & $-11.46 \%$ & $-88.53 \%$ \\
\hline
\end{tabular}

Sumber: Data Olahan

Tabel 2 Pertumbuhan Unit Penyertaan (UP) Periode 2009 - 2012

\begin{tabular}{clrrrr}
\hline$\#$ & RDS & $\mathbf{2 0 0 9 / 2 0 1 0}$ & $\mathbf{2 0 1 0 / 2 0 1 1}$ & $\mathbf{2 0 1 1} / \mathbf{2 0 1 2}$ & $\mathbf{2 0 0 9 - 2 0 1 2}$ \\
\hline 1 & Batavia_S & $-37.54 \%$ & $-15.01 \%$ & $337.56 \%$ & $132.28 \%$ \\
2 & Batavia & $-17.97 \%$ & $18.15 \%$ & $74.22 \%$ & $68.85 \%$ \\
3 & Trim_S & $-19.73 \%$ & $-26.02 \%$ & $59.34 \%$ & $-5.38 \%$ \\
4 & Manulife & $-31.38 \%$ & $-16.10 \%$ & $-16.74 \%$ & $-52.06 \%$ \\
5 & Mandiri_S & $2.79 \%$ & $-68.54 \%$ & $11.55 \%$ & $-63.92 \%$ \\
6 & NISP & $-22.99 \%$ & $-5.39 \%$ & $-52.63 \%$ & $-65.48 \%$ \\
7 & PNM_S & $-60.61 \%$ & $-10.59 \%$ & $-8.01 \%$ & $-67.60 \%$ \\
8 & BNP & $-59.49 \%$ & $-31.60 \%$ & $-5.99 \%$ & $-73.95 \%$ \\
9 & Danareksa & $-33.72 \%$ & $-48.08 \%$ & $-46.55 \%$ & $-81.61 \%$ \\
10 & CIMB_S & $-61.48 \%$ & $-71.89 \%$ & $-16.95 \%$ & $-91.01 \%$ \\
\hline
\end{tabular}

Sumber: Data Olahan

Dari tabel 1 dan 2 dapat kita lihat bahwa peringkat pertumbuhan NAV maupun UP tidak jauh berbeda. Batavia_S dan Batavia memiliki pertumbuhan NAV yang positif dan pertumbuhan UP yang positif pula. CIMB_S dan Danareksa menjadi reksa dana saham yang memiliki pertumbuhan yang negatif, baik itu pertumbuhan NAV maupun UP. Trim_S sebenarnya memiliki pertumbuhan NAV yang positif namun pertumbuhan UP yang dimiliki negatif. Meskipun begitu pertumbuhan UP negatif Trim_S tidak terlalu signifikan dibanding yang lain dengan memiliki pertumbuhan UP negatif diatas $50 \%$. 


\section{Analisis Annual Return}

Tabel 3 Perbandingan Annual Return RDS Syariah dengan Konvensional Periode 2009 - 2012

\begin{tabular}{|c|c|c|c|c|c|c|c|}
\hline Nama & 2009 & Nama & 2010 & Nama & 2011 & Nama & 2012 \\
\hline Batavia_S & $122.07 \%$ & IHSG & $46.13 \%$ & Trim_S & $6.93 \%$ & Trim_S & $18.13 \%$ \\
\hline Manulife & $113.96 \%$ & Manulife & $37.94 \%$ & IHSG & $3.20 \%$ & $\mathrm{BNP}^{-}$ & $16.37 \%$ \\
\hline BNP & $104.78 \%$ & Batavia & $37.67 \%$ & JII & $0.78 \%$ & Batavia_S & $15.39 \%$ \\
\hline NISP & $102.08 \%$ & BNP & $35.61 \%$ & Batavia & $-1.27 \%$ & Batavia & $14.98 \%$ \\
\hline Batavia & $100.67 \%$ & NISP & $32.80 \%$ & Manulife & $-2.54 \%$ & IHSG & $12.94 \%$ \\
\hline PNM_S & $97.24 \%$ & Trim_S & $29.59 \%$ & Danareksa & $-2.84 \%$ & JII & $10.76 \%$ \\
\hline CIMB_S & $93.22 \%$ & JII & $27.74 \%$ & NISP & $-3.18 \%$ & Manulife & $10.41 \%$ \\
\hline JII & $92.97 \%$ & Mandiri_S & $27.69 \%$ & Mandiri_S & $-3.91 \%$ & Danareksa & $9.63 \%$ \\
\hline Mandiri_S & $87.38 \%$ & Danareksa & $26.29 \%$ & CIMB_S & $-5.08 \%$ & Mandiri_S & $7.41 \%$ \\
\hline IHSG & $86.98 \%$ & CIMB_S & $26.01 \%$ & Batavia_S & $-5.32 \%$ & CIMB_S & $6.62 \%$ \\
\hline Danareksa & $83.02 \%$ & Batavia_S & $25.77 \%$ & $\mathrm{BNP}$ & $-7.63 \%$ & PNM_s & $5.55 \%$ \\
\hline Trim_S & $81.83 \%$ & PNM_S & $20.11 \%$ & PNM_S & $-12.97 \%$ & NISP & $4.24 \%$ \\
\hline
\end{tabular}

Sumber: Data Olahan

Berdasarkan tabel 3 dapat dilihat beberapa temuan sebagai berikut: (a) Danareksa menjadi satu-satunya reksa dana saham yang underperform dalam penelitian ini jika diperbandingkan dengan pasar. Mandiri_S memiliki kinerja yang tidak jauh berbeda dengan Danareksa yang selalu underperform jika diperbandingkan dengan kinerja pasar. Mandiri_S sempat memiliki kinerja yang outperform pada awal periode penelitian namun tidak mampu mempertahankan kinerja baiknya tersebut. (b) PNM_S dan CIMB_S menjadi reksa dana yang memiliki kinerja buruk dibanding semua reksa dana saham dalam penelitian ini. Meski outperform dibanding kinerja JII dan IHSG di awal periode, namun PNM_S dan CIMB_S tidak dapat mempertahankan kinerjanya sehingga underperform terhadap kinerja JII maupun IHSG selama 3 periode berikutnya. (c) Pada periode 2010 tidak ada satupun reksa dana saham yang mampu outperform terhadap kinerja pasar. (d) BNP, Batavia, dan Batavia_S, memiliki kinerja yang lebih stabil dibanding seluruh reksa dana saham yang ada. Keempat reksa dana saham tersebut mampu outperform terhadap kinerja pasar di awal dan diakhir periode penelitian. (e) Trim_S menjadi satu-satunya reksa dana saham yang menghasilkan annual return positif selama periode penelitian. Meskipun memiliki kinerja yang tidak lebih baik dari pasar (underperform) di awal periode, namun Trim_S dapat memperbaiki kinerjanya. Trim_S juga menjadi satu-satunya reksa dana saham yang dapat outperform terhadap kinerja pasar di periode 2011, dimana pada periode ini seluruh reksa dana menghasilkan annual return yang negatif.

\section{Analisis Risk Adjusted Return}

Tabel 4 Perbandingan Sharpe Ratio vs Treynor Ratio RDS Syariah dengan RDS Konvensional Periode 2009 - 2010

\begin{tabular}{lclclllc}
\hline Sharpe & $\mathbf{2 0 0 9}$ & Treynor & $\mathbf{2 0 0 9}$ & Sharpe & $\mathbf{2 0 1 0}$ & Treynor & $\mathbf{2 0 1 0}$ \\
\hline NISP & 0.17306 & Mandiri_S & 0.00335 & IHSG & 0.11430 & IHSG & 0.00146 \\
Manulife & 0.17034 & PNM_S & 0.00319 & Manulife & 0.09284 & Manulife & 0.00127 \\
IHSG & 0.16172 & Batavia_S & 0.00304 & Batavia & 0.08982 & Batavia & 0.00123 \\
BNP & 0.15645 & NISP & 0.00289 & NISP & 0.08310 & Mandiri_S & 0.00113 \\
Mandiri_S & 0.15601 & Manulife & 0.00276 & BNP & 0.08200 & NISP & 0.00108 \\
Batavia_S & 0.15277 & JII & 0.00271 & Mandiri_S & 0.07552 & BNP & 0.00108 \\
\hline
\end{tabular}




\begin{tabular}{llllllll}
\hline JII & 0.14799 & BNP & 0.00268 & Trim_S & 0.06427 & Trim_S & 0.00101 \\
Batavia & 0.14272 & CIMB_S & 0.00265 & JII & 0.06362 & Batavia_S & 0.00094 \\
CIMB_S & 0.13836 & IHSG & 0.00254 & CIMB_S & 0.06136 & JII & 0.00093 \\
PNM_S & 0.13756 & Trim_S & 0.00252 & Batavia_S & 0.06119 & CIMB_S & 0.00092 \\
Danareksa & 0.11717 & Batavia & 0.00247 & Danareksa & 0.05877 & Danareksa & 0.00081 \\
Trim_S & 0.11282 & Danareksa & 0.00221 & PNM_S & 0.04695 & PNM_S & 0.00077 \\
\hline
\end{tabular}

\begin{tabular}{l}
\hline OutPerform \\
OutPerform (> JII atau $>$ IHSG) \\
UnderPerform
\end{tabular}

Sumber: Data Olahan

Dari Tabel 4 dapat dilihat bahwa pada 2009 baik reksa dana saham syariah maupun reksa dana saham konvensional tidak ada yang memiliki peringkat yang sama pada Sharpe Ratio dan Treynor Ratio. Ini menandakan bahwa pada periode 2009 seluruh reksa dana saham syariah maupun konvensional tidak ada yang terdiversifikasi dengan optimal. Dari segi portofolio pasar (pasif) pun tidak ada yang memiliki peringkat yang sama, baik itu JII maupun IHSG. Pada 2010 Manulife, Batavia memiliki peringkat yang sama dan mampu outperform terhadap kinerja pasar syariah yaitu JII sedangkan underperform jika dibandingkan dengan kinerja pasarnya yaitu IHSG. Trim_S juga memiliki peringkat Sharpe dan Jensen ratio yang sama dan mampu outperform terhadap kinerja pasarnya yaitu JII namun underperform terhadap kinerja portofolio pasar konvensional yaitu IHSG.

Tabel 5 Perbandingan Sharpe Ratio vs Treynor Ratio RDS Syariah dengan RDS Konvensional Periode 2011 - 2012

\begin{tabular}{lclrlclc}
\hline \multicolumn{1}{c}{ Sharpe } & $\mathbf{2 0 1 1}$ & Treynor & $\mathbf{2 0 1 1}$ & Sharpe & $\mathbf{2 0 1 2}$ & Treynor & $\mathbf{2 0 1 2}$ \\
\hline Trim_S & 0.01381 & Trim_S & 0.00024 & Trim_S & 0.05548 & Trim_S & 0.00068 \\
IHSG & 0.00377 & IHSG & 0.00006 & BNP & 0.05045 & Batavia_S & 0.00049 \\
JII & -0.00092 & JII & -0.00002 & Batavia_S & 0.04868 & BNP & 0.00045 \\
Batavia & -0.00659 & Batavia & -0.00010 & Batavia & 0.04721 & Batavia & 0.00043 \\
Manulife & -0.00921 & Manulife & -0.00014 & IHSG & 0.04101 & IHSG & 0.00035 \\
NISP & -0.01236 & NISP & -0.00019 & JII & 0.03010 & JII & 0.00031 \\
Danareksa & -0.01287 & Danareksa & -0.00020 & Manulife & 0.02783 & Manulife & 0.00025 \\
Mandiri_S & -0.01693 & Batavia_S & -0.00027 & Danareksa & 0.02490 & Danareksa & 0.00022 \\
CIMB_S & -0.01741 & Mandiri_S & -0.00028 & Mandir_S & 0.01863 & Mandiri_S & 0.00020 \\
Batavia_S & -0.01865 & CIMB_S & -0.00029 & CIMB_S & 0.01559 & CIMB_S & 0.00017 \\
BNP & -0.02111 & BNP & -0.00032 & PNM_S & 0.01108 & PNM_S & 0.00014 \\
PNM_S & -0.03595 & PNM_S & -0.00061 & NISP & 0.00330 & NISP & 0.00003 \\
\hline
\end{tabular}

OutPerform

OutPerform (> JII atau >IHSG)

UnderPerform

Sumber: Data Olahan

Pada table 5 terlihat bahwa hampir seluruh reksa dana saham memiliki peringkat yang sama dalam pengukuran Sharpe Ratio dan Treynor Ratio. Ini menandakan bahwa seluruh reksa dana saham melakukan perubahan agar portofolio yang dimiliki terdiversifikasi dengan optimal. Namun masih ada beberapa reksa dama saham yang masih memiliki peringkat Sharpe ratio dan Treynor ratio yang berbeda 
Tabel 6 Perbandingan Jensen Ratio RDS Syariah dengan RDS Konvensional Periode 2009 - 2012

\begin{tabular}{lclllllc}
\hline \multicolumn{1}{c}{ Jensen } & $\mathbf{2 0 0 9}$ & Jensen & $\mathbf{2 0 1 0}$ & \multicolumn{1}{c}{ Jensen } & $\mathbf{2 0 1 1}$ & \multicolumn{1}{c}{ Jensen } & $\mathbf{2 0 1 2}$ \\
\hline Mandiri_S & 0.00050 & Mandiri_S & 0.00016 & Trim_S & 0.00024 & Trim_S & 0.00031 \\
PNM_S & 0.00044 & Trim_S & 0.00009 & Batavia & -0.00016 & Batavia_S & 0.00017 \\
Batavia_S & 0.00037 & CIMB_S & -0.00001 & Manulife & -0.00021 & BNP & 0.00010 \\
NISP & 0.00036 & Batavia_S & -0.00006 & Mandiri_S & -0.00023 & Batavia & 0.00008 \\
Manulife & 0.00026 & PNM_S & -0.00014 & Danareksa & -0.00024 & Mandiri_S & -0.00010 \\
BNP & 0.00017 & Manulife & -0.00018 & NISP & -0.00025 & Manulife & -0.00011 \\
CIMB_S & -0.00006 & Batavia & -0.00022 & CIMB_S & -0.00026 & CIMB_S & -0.00012 \\
Batavia & -0.00007 & Danareksa & -0.00071 & Batavia_S & -0.00027 & PNM_S & -0.00014 \\
Trim_S & -0.00018 & NISP & -0.00036 & BNP & -0.00042 & Danareksa & -0.00014 \\
Danareksa & -0.00036 & BNP & -0.00041 & PNM_S & -0.00059 & NISP & -0.00034 \\
\hline
\end{tabular}

RDS Syariah
RDS Konvensional

Sumber: Data Olahan

Dari Tabel 6 dapat diketahui bahwa kinerja reksa dana saham syariah lebih baik dibanding kinerja reksa dana saham konvensional. Selama periode penelitian hanya reksa dana saham syariah yang memiliki wakil dengan kinerja portofolio yang menghasilkan $\alpha_{\mathrm{p}}$ positif meskipun tidak selalu sama. Reksa dana saham konvensional hanya memiliki wakil dengan kinerja portofolio yang menghasilkan $\alpha_{p}$ positif pada periode 2009 dan 2012. CIMB_S dan Danareksa menjadi portofolio yang selama periode penelitian berlangsung tidak pernah menghasilkan $\alpha_{\mathrm{p}}$ positif.

Dari pengukuran Sharpe Ratio, Treynor Ratio, dan Jensen Ratio hanya ada dua periode dimana reksa dana saham syariah maupun konvensional dapat melewati ketiga pengukuran tersebut, yaitu: (a) Pada Periode 2011: Trim_S. (2) Pada Periode 2012: Trim_S dan Batavia. Data di atas merupakan reksa dana saham dengan kinerja yang baik di pengukuran Sharpe Ratio, Treynor Ratio, maupun Jensen Ratio. Periode 2009 dan 2010 tidak dapat diikutsertakan karena pada periode tersebut tidak ada reksa dana yang memenuhi syarat Sharpe Ratio dan Jensen Ratio baik itu reksa dana saham syariah maupun konvensional, meskipun pada Jensen Ratio terdapat portofolio yang memiliki $\alpha_{\mathrm{p}}$ positif.

\section{Analisis Snail Trail}

Dapat dilihat bagaimana metode Snail Trail mengevaluasi kinerja reksa dana saham syariah maupun konvensional. Pada metode Snail Trail ada dua hal yang dapat diperhatikan, yaitu: (a) Return portofolio reksa dana saham syariah maupun konvensional dibandingkan dengan return portofolio pasar. JII dalam hal ini sebagai portofolio pasar syariah dan IHSG sebagai portofolio pasar konvensional. Kinerja return portofolio dapat dilihat pada sumbu Y (Vertikal) pada grafik Snail Trail. (b) Risiko portofolio reksa dana saham syariah maupun konvensional dibandingkan dengan risiko portofolio pasar. JII dalam hal ini sebagai portofolio pasar syariah dan IHSG sebagai portofolio pasar konvensional. Kinerja risiko portofolio dapat dilihat pada sumbu X (Horizontal) pada grafik Snail Trail.

Seperti yang telah di jelaskan bahwa metode Snail Trail akan menggambarkan kinerja reksa dana saham (return dan risiko) dari waktu ke waktu. Warna dari masing-masing kurva pada grafik Snail Trail akan dibedakan menjadi empat agar perubahan kinerja reksa dana saham syariah maupun konvensional dapat terlihat. Empat warna kurva tersebut adalah: (a) Garis warna biru menggambarkan kinerja untuk periode 2009. (b) Garis warna coklat menggambarkan kinerja untuk periode 2010. (c) Garis warna hijau menggambarkan kinerja untuk periode 2011. (d) Garis warna ungu menggambarkan kinerja untuk periode 2012. 
Tabel 7 Analisis Snail Trail - Kuadran I

\begin{tabular}{clc}
\hline \# & Kwadrant 1 & \% \\
\hline 1 & Mandiri Syariah & $15 \%$ \\
2 & Batavia Syariah & $15 \%$ \\
3 & Trim Syariah & $13 \%$ \\
4 & PNM Syariah & $11 \%$ \\
5 & NISP & $9 \%$ \\
6 & Danareksa & $4 \%$ \\
7 & Manulife & $2 \%$ \\
8 & BNP & $2 \%$ \\
9 & Batavia & $2 \%$ \\
10 & CIMB Syariah & $2 \%$ \\
\hline
\end{tabular}

Sumber: Data Olahan

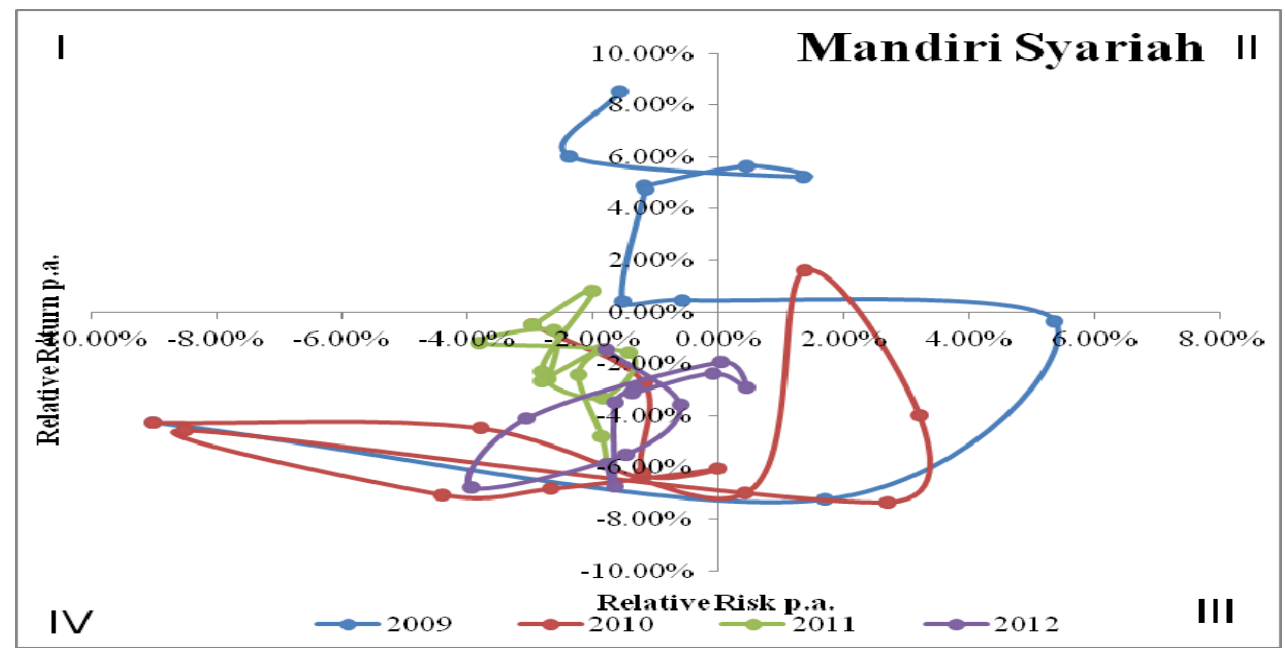

Gambar 2 Kinerja Terbaik RDS Mandiri Syariah Sumber: Data Olahan

Tabel 8 Analisis Snail Trail - Kuadran III

\begin{tabular}{clc}
\hline \# & \multicolumn{1}{c}{ Kwadrant 3 } & \% \\
\hline 1 & Danareksa & $57 \%$ \\
2 & Batavia & $49 \%$ \\
3 & BNP & $38 \%$ \\
4 & Manulife & $30 \%$ \\
5 & Trim Syariah & $28 \%$ \\
6 & PNM Syariah & $26 \%$ \\
7 & NISP & $23 \%$ \\
8 & Mandiri Syariah & $15 \%$ \\
9 & CIMB Syariah & $15 \%$ \\
10 & Batavia Syariah & $6 \%$ \\
\hline
\end{tabular}

Sumber: Data Olahan 


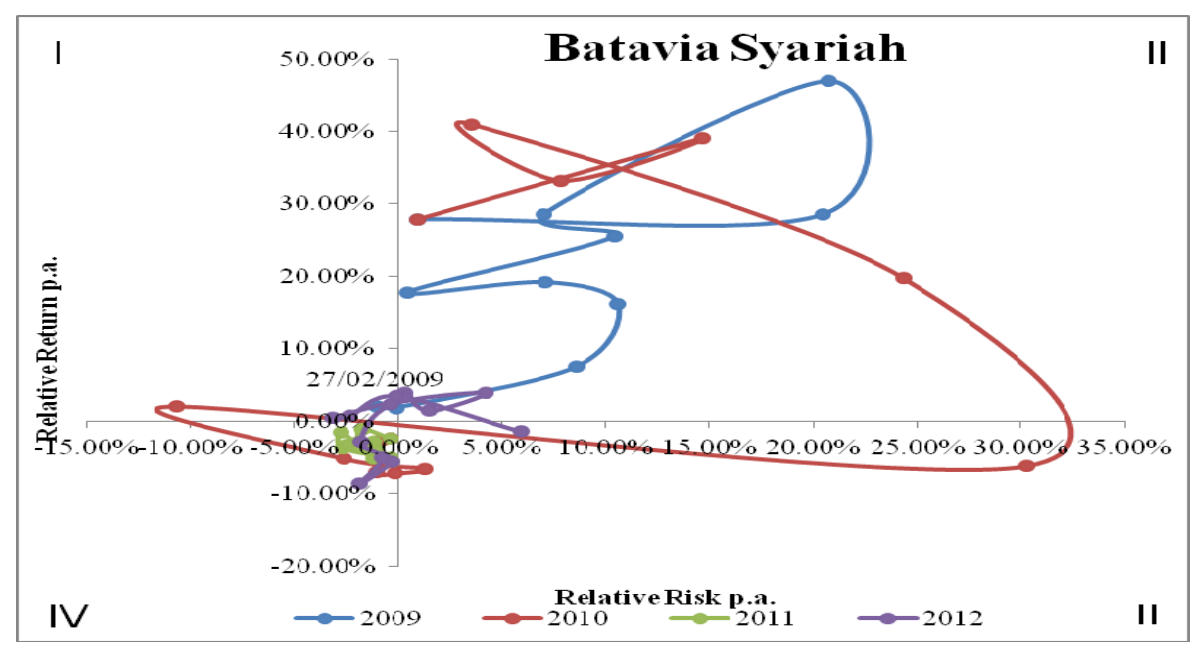

Gambar 3 Kinerja Terbaik RDS Batavia Syariah Sumber: Data Olahan

\section{SIMPULAN}

Dari tabel 1 dapat kita lihat bahwa reksa dana saham syariah lebih baik dibandingkan dengan reksa dana saham konvensional. Reksa dana saham syariah memiliki Batavia_S dan Trim_S dengan pertumbuhan Net Asset Value (NAV) yang positif selama periode penelitian, sedangkan dari reksa dana saham konvensional hanya Batavia yang memiliki pertumbuhan NAV yang positif. Namun dari segi besaran NAV yang dimiliki masing-masing reksa dana saham, reksa dana saham konvensional lebih baik dibandingkan dengan reksa dana saham syariah.

Jika melihat dari segi pertumbuhan unit penyertaan (UP) pada tabel 1.2, baik reksa dana saham syariah maupun konvensional hanya memiliki satu produk dengan pertumbuhan UP yang positif yaitu Batavia_S mewakili reksa dana saham syariah dan Batavia mewakili reksa dana saham konvensional. Namun Batavia_S lebih baik, karena Batavia_S memiliki pertumbuhan Up diatas 100\% selama periode penelitian.Trim_S memiliki pertumbuhan yang lebih baik jika dibandingkan dengan reksa dana saham yang memiliki pertumbuhan UP negatif baik itu syariah maupun konvensional. Dari Segi jumlah UP yang dimiliki masing-masing reksa dana saham, reksa dana saham konvensional yang lebih unggul.

Dari analisis risk adjusted return berdasarkan Sharpe Ratio, Treynor Ratio, Jensen Ratio kinerja reksa dana saham syariah lebih baik dibandingkan dengan kinerja reksa dana konvensional. Ini terbukti dari hasil analisis risk adjusted return selama periode penelitian hanya reksa dana saham syariah yang memiliki produk pada setiap periode penelitian yang mampu outperform terhadap pasar, meskipun tidak ada yang secara konsisten dan stabil outperform terhadap pasar. Sedangkan reksa dana saham konvensional hanya pada periode 2009 (NISP dan Manulife) dan 2010 (BNP dan Batavia) memiliki produk yang mampu outperform terhadap pasar.

Seperti yang kita ketahui dari analisis sebelumnya yaitu analisis annual return dan risk adjusted return, kinerja reksa dana saham syariah dan konvensional tidak selalu konsisten dan stabil. Oleh karena itu, penilaian kinerja reksa dana saham tidak cukup hanya menggunakan data historis satu tahun saja. Evaluasi harus dilakukan dengan data historis yang panjang dan harus dilakukan cut-off period per tahunnya. Evaluasi kinerja reksa dana saham menggunakan metode Snail Trail dapat membantu mengevaluasi reksa dana saham dengan data historis multi-years serta mempelajari kinerja 
reksa dana dari segi return dan manajemen risiko. Ouput yang dihasilkan dari metode Snail Trail adalah gambaran kinerja reksa dana dari waktu ke waktu dan sangat detil serta mudah untuk dipahami.

Dari hasil uji statistik yang dilakukan terhadap kinerja reksa dana saham syariah dan konvensional selama empat periode $(2009,2010,2011,2012)$ menunjukkan tidak adanya perbedaan rata-rata kinerja antara reksa dana saham syariah maupun reksa dana saham syariah dan layak untuk diperbandingkan. Dari semua hasil analisis dapat disimpulkan bahwa dari 10 reksa dana saham yang diteliti, kinerja reksa dana saham syariah lebih baik dibandingkan dengan reksa dana saham konvensional. Secara statistik juga menunjukkan bahwa kinerja reksa dana saham syariah dan konvensional tidak jauh berbeda dengan Significance level yang digunakan adalah sebesar 0.05 atau dengan confidence level sebesar $95 \%$.

Dari hasil kesimpulan tersebut, beberapa saran dapat diberikan untuk perbaikan di masa depan. Dalam melakukan evaluasi kinerja portofolio sebaiknya menggunakan data historis yang panjang dan cut-off period per tahunnya agar bisa terlihat kinerja portofolio dari waktu ke waktu serta dapat terlihat apakah portofolio yang diteliti mengalami perubahan atau tidak. Evaluasi kinerja portofolio lebih baik dilakukan pada saat kondisi pasar abnormal. Karena dengan begitu dapat terlihat portofolio mana yang dapat mengelola risiko dengan baik. Penelitian yang akan datang diharapkan cakupan reksa dana yang dievaluasi dan diperbandingkan lebih diperluas, mungkin tidak hanya pada reksa dana jenis saham namun dari jenis campuran, pendapatan tetap, terproteksi maupun reksa dana indeks.

Pada umumnya benchmark yang digunakan adalah IHSG untuk konvensional dan JII untuk syariah. Untuk yang akan datang mungkin bisa menggunakan LQ-45 untuk konvensional dan ISSI untuk syariah. ISSI merupakan indeks yang baru diluncurkan pada 2011 yang berisikan saham-saham syariah yang sesuai dengan Daftar Efek Syariah (DES). Ataupun bisa menggunakan satu benchmark seperti menggunakan indeks reksa dana saham yang dibuat oleh Invofesta dimana indeks tersebut menggambarkan bagaimana kondisi reksa dana saham yang ada di Indonesia.

Dapat memberikan informasi kepada investor maupun calon investor mengenai bagaimana kinerja reksa dana saham syariah yang diperbandingkan dengan reksa dana saham konvensional dan dapat menjawab keragu-raguan dalam melakukan investasi syariah yang disebabkan adanya proses screening dan cleansing dalam produk investasi yang menerapkan prinsip-prinsip syariah.

\section{DAFTAR PUSTAKA}

Brown, Keith C., Reilly, Frank, K. (2009). Analysis of investments and management of portfolios (9 $9^{\text {th }}$ ed). South-Western, United States of America: Cengage Learning

Gunawan, H. (2010). Kinerja Reksa Dana Indonesia pada Saat Bullish Market, Crash Market, dan Rebound Market. Tesis S2 Tidak Dipublikasikan, Universitas Indonesia, Jakarta.

Heykal, M. (2012). Tuntunan dan Aplikasi Investasi Syariah. Jakarta: Elex Media Komputindo

Huda, Nurul, Nasution, M. E. (2007). Investasi Pada Pasar Modal Syariah. Jakarta: Penerbit Kencana Prenada Media Group

Nafik HR, M. (2009). Bursa Efek \& Investasi Syariah. Jakarta: Penerbit Serambi 
Rachmawati, A. (2008). Komparasi kinerja reksadana Syariah dan reksadana konvensional kategori saham, campuran, dan pendapatan tetap di Indonesia periode Maret 2005-Maret 2008. Skripsi S1 Tidak Dipublikasikan, Universitas Indonesia, Jakarta.

Ridho, A. (2008). Perbandingan kinerja reksa dana konvensional dan syariah dengan indeks sharpe, treynor dan jensen (periode tahun 2003-2007). Tesis S2 Tesis S2 Tidak Dipublikasikan, Universitas Indonesia, Jakarta.

Situmorang, P., Mahardika, J., Listiyarni, T. (2010). Langkah Awal Berinvestasi Reksa Dana. Jakarta: Penerbit Transmedia Pustaka

Tifany. (2010). Analisis Kinerja Reksa Dana Saham Syariah Periode Januari 2009 - Desember 2009. Skripsi S1 Tidak Dipublikasikan, Universitas Bina Nusantara, Jakarta 